[MK]

\title{
Sr isotopic composition of hydroxyapatite from recent and fossil salmon: the record of lifetime migration and diagenesis
}

\author{
Paul L. Koch ${ }^{\mathrm{a}, \mathrm{b},} *$, Alex N. Halliday ${ }^{\mathrm{a}}$, Lynn M. Walter ${ }^{\mathrm{a}}$, Ralph F. Stearley ${ }^{\mathrm{a}, \mathrm{b},}$ **, \\ Ted J. Huston ${ }^{a}$ and Gerald R. Smith ${ }^{\text {a,b }}$ \\ a Department of Geological Sciences, University of Michigan, Ann Arbor, MI 48109, USA \\ ${ }^{b}$ Museum of Paleontology, University of Michigan, Ann Arbor, MI 48109, USA
}

Received January 8, 1991; revision accepted December 16, 1991

\section{ABSTRACT}

\begin{abstract}
By comparing the $\mathrm{Sr}$ isotopic composition of migratory fossil salmon, which lived in the ocean but died in continental regions, to the well established marine Sr isotopic record, the age of the continental deposit could be determined with high accuracy. This approach to marine-continental correlation and dating requires (1) that marine-resident salmon bear a marine ${ }^{87} \mathrm{Sr} /{ }^{86} \mathrm{Sr}$ value in their bones or teeth, and (2) that the original ${ }^{87} \mathrm{Sr} /{ }^{86} \mathrm{Sr}$ value of fossils is not overprinted by diagenesis. The vertebrae of modern, hatchery-reared salmon exhibit $\mathrm{Sr}$ isotopic variations indicative of freshwater to marine migration during bone growth. Modern marine ${ }^{87} \mathrm{Sr} /{ }^{86} \mathrm{Sr}$ values were preserved in growth layers formed later in life. Marine-phase growth layers in the bones and teeth of the late Miocene migratory salmon, Oncorhynchus rastrosus, were subjected to stepwise selective leaching to separate biogenic hydroxyapatite from diagenetic calcium carbonate and recrystallized hydroxyapatite. Although the procedure yielded leachates with $\mathrm{Sr} / \mathrm{Ca}$ and $\mathrm{Ca} / \mathrm{P}$ values characteristic of apatite, the leachates had ${ }^{87} \mathrm{Sr} /{ }^{86} \mathrm{Sr}$ values consistently less radiogenic than values for late Miocene seawater $(\sim 0.7087)$. The fossils were substantially contaminated by Sr from the hosting clastic sediments. Specimens in continental deposits differed in ${ }^{87} \mathrm{Sr} /{ }^{86} \mathrm{Sr}$ value from host sediments by 0.0002 to 0.0200 , supporting the conclusion that these salmon were migrants from marine waters. However, because the original $S_{r}$ isotopic composition of fossil bones and teeth cannot be determined with confidence, archaeological, paleobiological and stratigraphic applications of this technique may be limited.
\end{abstract}

\section{Introduction}

Vertebrate bones and teeth are composed of hydroxyapatite that contains trace amounts of $\mathrm{Sr}$ substituted for $\mathrm{Ca}-(\mathrm{Ca}, \mathrm{Sr})_{5}\left(\mathrm{PO}_{4}, \mathrm{CO}_{3}\right)_{3}(\mathrm{OH}, \mathrm{F}, \mathrm{Cl})$ [1]. Unlike organic remains, which usually decay soon after death, mineralized parts can persist for millions of years. The concentration and isotopic composition of $\mathrm{Sr}$ in bones and teeth have served as diagnostic tools in archaeological [2-6], pale-

\footnotetext{
* Current address: Department of Paleobiology, NHB-E207 MRC 121, Smithsonian Institution, Washington, D.C. 20560, USA, and Carnegie Institution of Washington, Geophysical Laboratory, 5251 Broad Branch Rd., N.W., Washington, D.C. 20015, USA.

** Current address: Department of Paleontology, Illinois State Museum, Springfield, IL, USA.
}

ontological [7,8], and paleoceanographic [9-11] investigations. The pronounced secular variations in the ${ }^{87} \mathrm{Sr} /{ }^{86} \mathrm{Sr}$ value of ocean water throughout the Phanerozoic have rendered $\mathrm{Sr}$ isotope analysis particularly useful for marine stratigraphic correlation $[12,13]$. Migratory fish, such as salmon, could potentially be used for continental-marine correlation. Many salmon migrate from freshwater to the ocean several years after hatching, spend much of their lives growing in the ocean, then return to freshwater to spawn and die. If a marine $\mathrm{Sr}$ isotope composition is preserved in fossil salmon deposited after spawning in freshwater, then this continental site could be dated by reference to the well known marine $\mathrm{Sr}$ isotope record.

Two questions fundamental to this approach to marine-continental correlation are addressed. First, are both the freshwater and marine phases 
of life preserved in the bone of living salmon? Because freshwater and marine ${ }^{87} \mathrm{Sr} /{ }^{86} \mathrm{Sr}$ values are typically very different, it must be verified that a portion of salmon bone retains a fully marine Sr isotopic signature. To explore this issue, accreted tissues of modern, hatchery-reared salmon with known migrational histories were analyzed for isotopic evidence of freshwater to marine migration. Second, can a marine chemical signal be retrieved from fossil salmon, or does diagenesis overwhelm the original ${ }^{87} \mathrm{Sr} /{ }^{86} \mathrm{Sr}$ value of fish apatite? Preservation was investigated in salmon of late Miocene age, through application of a selective leaching technique that has been used previously $[6,14]$ to separate biogenic and diagenetic Sr. If ${ }^{87} \mathrm{Sr} /{ }^{86} \mathrm{Sr}$ values characteristic of late Miocene oceans cannot be retrieved from individuals buried in continental and nearshore marine clastic sediments, our approach to marine-continental correlation is unworkable.

\section{Diagenetic alteration of biogenic hydroxyap- atite}

Studies of diagenetic effects on $\mathrm{Sr}$ in biogenic hydroxyapatite have yielded equivocal results. Experiments indicated a high potential for invasion of biogenic apatite by $\mathrm{Sr}[15,16]$, whereas evidence from fossils suggested retention of in vivo concentrations $[17,18]$. In a comparative study of modern and Holocene mammals, Nelson et al. [19] were unable to retrieve original $\mathrm{Sr}$ concentrations or isotopic values from fossils. In contrast, Sealy et al. [6] used stepwise selective leaching to remove diagenetic $\mathrm{Sr}$ and recovered $\mathrm{Sr}$ concentrations and isotopic values that they considered to be primary.

Diagenetic $\mathrm{Sr}$ enters biogenic hydroxyapatite by several mechanisms. Calcite and other Srbearing minerals may precipitate in pore spaces within bones and teeth [14]. Diagenetic Sr may be adsorbed to crystal surfaces in hydration layers [15]. Biogenic hydroxyapatite is a poorly crystalline mineral composed of very small crystallites $(\sim 20 \times 4 \mathrm{~nm}[1,14])$ that offer a great surface area for adsorption. During diagenesis, these small crystals consolidate and grow, due to local dissolution and reprecipitation (i.e., Ostwald ripening $[16,20])$. The resulting mineral is more perfectly crystalline and less soluble than the original biogenic hydroxyapatite, but it contains $\mathrm{Sr}$ incorporated from the depositional environment $[21,22]$.

Because the diagenetic minerals and biogenic hydroxyapatite have different solubilities in acidic solutions, they may be chemically separable by stepwise selective leaching [14,23]. More soluble calcium carbonate would be removed preferentially, followed by less soluble biogenic hydroxyapatite. Recrystallized hydroxyapatite should be relatively insoluble. In tests on altered bones using a dilute acetic acid/sodium acetate buffer, late rinses had apatitic $\mathrm{Ca} / \mathrm{P}$ and plausible $\mathrm{Sr} / \mathrm{Ca}$ values, and thus may have dissolved unaltered biogenic hydroxyapatite [23]. In coupled analyses of the $\mathrm{Sr}$ concentration and isotopic composition of Quaternary specimens, Sealy et al. [6] discovered that diagenetic $\mathrm{Sr}$ was indeed removed preferentially in early rinses. However, for all but one of their test specimens, they could not unequivocally demonstrate that only biogenic Sr was contained in late rinses, because the original ${ }^{87} \mathrm{Sr} /$ ${ }^{86} \mathrm{Sr}$ values of the specimens were unknown. Using bone from a marine-resident whale recovered from a continental deposit, they were able to demonstrate that only biogenic, marine $\mathrm{Sr}$ was released in late rinses. Our test using salmon is similar, because the primary, marine and secondary, diagenetic $\mathrm{Sr}$ isotopic endmembers for these late Miocene fossils can be well constrained. In contrast to Sealy et al. [6], however, we examined ancient specimens with a preservation state similar to that in specimens used for paleontological and geological studies.

\section{Salmon samples}

Information about modern salmon and water samples is supplied in Table 1. Samples were cleaned of soft tissue manually and by dermestid beetles. We sequentially microsampled material from the center to the periphery of vertebral centra with a dental drill (Fig. 1). Vertebral centra grow by centrifugal accretion, with no conspicuous remodeling, thus samples from the center of vertebrae represent bone formed during the early, freshwater phase of the life cycle. Bulk samples, representing the later, marine phase of life, were obtained from the middle to the edge of vertebral centra. Modern samples were roasted 
TABLE 1

Sr isotopic composition of modern salmon and hatchery waters

\begin{tabular}{llll}
\hline S. salar & $\begin{array}{l}\text { O. kisutch } \\
\text { UMMZ 186653 }\end{array}$ & $\begin{array}{l}\text { O. kisutch } \\
\text { UMMZ 186654 }\end{array}$ & $\begin{array}{l}\text { O. nerka } \\
\text { UMMZ 94902 }\end{array}$ \\
\hline $\begin{array}{l}\text { Hatchery water } \\
0.719027 \pm 12\end{array}$ & $0.703644 \pm 14$ & - & - \\
Center of vertebra & & & $0.709293 \pm 24$ \\
$0.711376 \pm 43$ & $0.709025 \pm 24$ & $0.709000 \pm 99$ & $0.709230 \pm 21$ \\
$0.709851 \pm 31$ & $0.709204 \pm 40$ & $0.709184 \pm 43$ & $0.709240 \pm 20$ \\
$0.709296 \pm 20$ & $0.709233 \pm 33$ & $0.709204 \pm 43$ & $0.709247 \pm 31$ \\
$0.709284 \pm 17$ & $0.709293 \pm 38$ & $0.709254 \pm 47$ & $0.709238 \pm 30$ \\
$0.709309 \pm 16$ & $0.709213 \pm 38$ & $0.709220 \pm 65$ & \\
Edge of vertebra & & & - \\
- & $0.709193 \pm 27$ & $0.709222 \pm 26$ & \\
\hline
\end{tabular}

Hatchery-reared salmon and waters were supplied by the Craig Brook National Fish Hatchery, East Orland, ME ( $S$. salar), and the Bonneville Fish Hatchery, Cascade Locks, OR (UMMZ 186653). The remaining specimens were obtained from museum collections and were originally collected in the Pacific Ocean at the mouths of the Columbia (UMMZ 186654) and Quinault (UMMZ 94902) rivers. $\mathrm{UMMZ}=$ University of Michigan Museum of Zoology. Errors are reported as $\pm 2 \sigma$.

in $\mathrm{Pt}$ boats at $600-700^{\circ} \mathrm{C}$ for $24 \mathrm{~h}$ to oxidize the organic matrix of bones and teeth.

salmon, Oncorhynchus rastrosus, collected in ma-

We analyzed museum specimens of the fossil rine and continental deposits of late Miocene Hemphillian Land Mammal Age (5-9 Ma) [24]
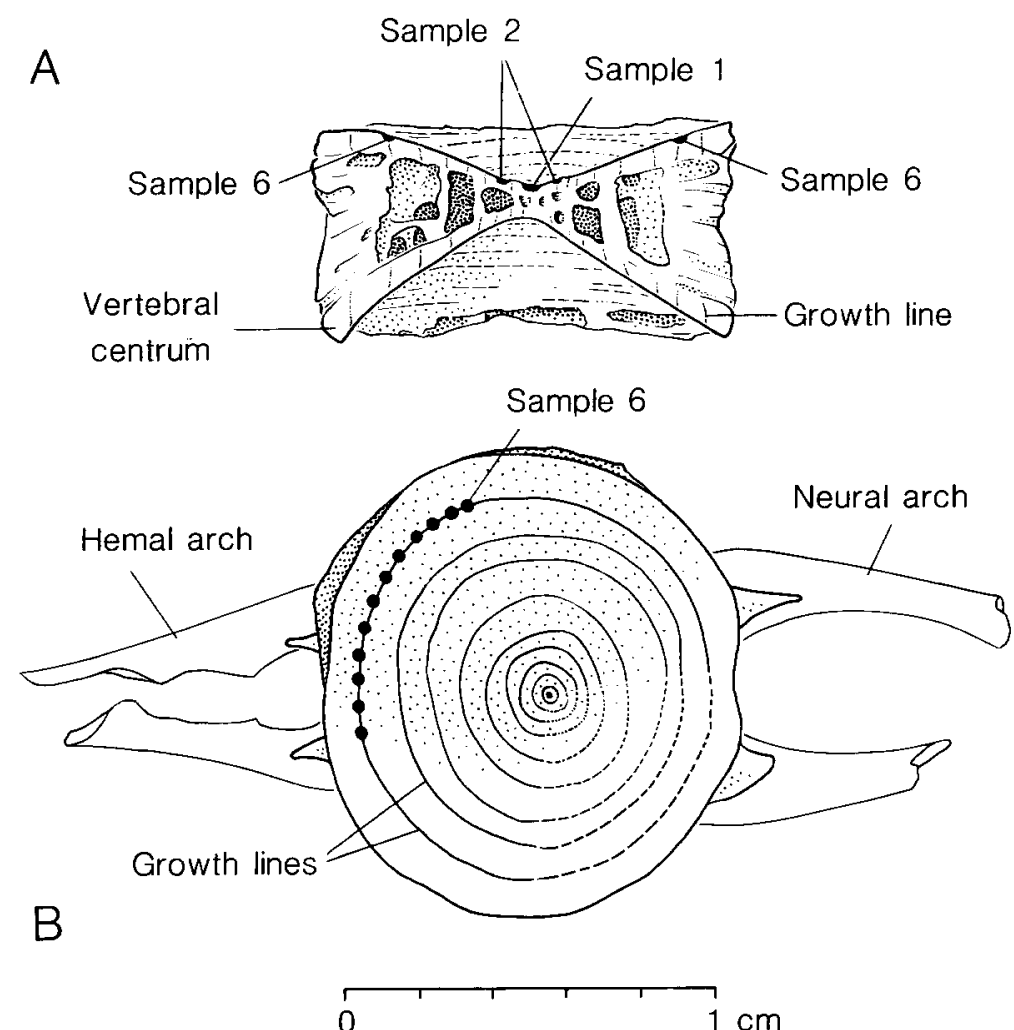

Fig. 1. Drawing of a salmon vertebra showing the relationship between growth structures and sample positions. (A) A cross-section of a vertebra, exhibiting the thickness of vertebral centra and the depth of sample pits. (B) A plan view of a vertebra showing the pattern of growth lines. 
from California and Oregon (Table 2). Bulk sediment samples were scraped directly from fossils. Fossils were rinsed and sonicated in distilled water to remove remaining sediment. Bulk samples of marine growth were collected as for the modern specimens. Enamel was sampled from a large premaxillary tooth from the Turlock Lake locality to compare preservation between tooth enamel and bone. This tooth is diagnostic of Oncorhynchus rastrosus, and due to its great size, must have formed in a large ocean-resident individual. Because enamel has larger crystals and is less porous than bone, enamel apatite should be less susceptible to diagenetic alteration $[1,6,14]$.

The utility of our analysis depends on the assessment of Oncorhynchus rastrosus as a migratory species. Although most modern salmon spend much of their lifetime in the ocean, migration patterns do vary between and within species [25]. Some species of salmon live only in freshwater. Others have both individuals that migrate early in life from freshwater to marine water and individuals that do not migrate. $O$. rastrosus has been recovered from both continental and marine deposits, verifying that at least some individuals migrated. Furthermore, recent systematic investigations demonstrate that $O$. rastrosus was a $\mathrm{Pa}$ cific salmon [26,27], and a member of a sublineage that includes almost exclusively migratory species. Finally, in modern Oncorhynchus species with both migratory and non-migratory individuals, there are conspicuous differences in size and morphology between freshwater and ocean-going individuals. Freshwater individuals are smaller than migratory conspecifics (e.g., rainbow trout vs. steelhead). $O$. rastrosus is by far the largest salmon known, reaching lengths in excess of $2 \mathrm{~m}$; some of the largest specimens have been recovered from continental deposits. It is unlikely that permanent residents in small rivers and freshwater lakes would reach such large sizes. For example, a large Miocene lake in southwest Idaho contains a sister species to $O$. rastrosus with individuals less than $0.7 \mathrm{~m}$ long [28]. Thus all available evidence supports the conclusion that Oncorhynchus rastrosus was an exclusively migratory species. Adult specimens found in freshwater deposits were not lifelong residents, but instead were immigrants that entered the habitat immediately prior to death.

\section{Analytical techniques}

Procedures for stepwise selective leaching were modified from Sillen [23]. Samples (20-50 mg) were sonicated for $1 \mathrm{~min}$ in $0.1 \mathrm{~N}$ acetic acid buffered to $\mathrm{pH} 4.5$ with lithium acetate, using $0.04 \mathrm{ml}$ solution $/ \mathrm{mg}$ sample powder. The mixture was centrifuged at $13,000 \mathrm{rpm}$ for $30 \mathrm{~s}$, then the solution was decanted to form a single rinse. This

TABLE 2

Sr isotopic composition of Hemphillian (late Miocene) fossil salmon, Oncorhynchus rastrosus, and bulk sediment at burial sites

\begin{tabular}{|c|c|c|c|c|c|}
\hline & $\begin{array}{l}\text { Gateway } \\
\text { vertebra } \\
\text { UMMP } 58062 \\
\text { (C) }\end{array}$ & $\begin{array}{l}\text { Turlock Lake } \\
\text { tooth } \\
\text { UCMP } 136029 \\
\text { (C) }\end{array}$ & $\begin{array}{l}\text { Turlock Lake } \\
\text { vertebra } \\
\text { UCMP } 136030 \\
\text { (C) }\end{array}$ & $\begin{array}{l}\text { Loretta Street } \\
\text { vertebra } \\
\text { UCMP } 119996 \\
\text { (M) }\end{array}$ & $\begin{array}{l}\text { Drakes Bay } \\
\text { vertebra } \\
\text { UCMP } 136028 \\
\text { (M) }\end{array}$ \\
\hline Bulk sediment & $0.703721 \pm 25$ & - & $0.706011 \pm 14$ & $0.707236 \pm 13$ & $0.707682 \pm 14$ \\
\hline $0.1 \mathrm{~N}$ Acetic: 1 & $0.704410 \pm 18$ & $0.706697 \pm 21$ & $0.706200 \pm 14$ & $0.708605 \pm 13$ & $0.708302 \pm 16$ \\
\hline $0.1 \mathrm{~N}$ Acetic: $9+10$ & - & $0.706721 \pm 27$ & $0.706219 \pm 23$ & - & - \\
\hline $0.1 \mathrm{~N}$ Acetic: $17+18$ & - & $0.706701 \pm 27$ & $0.706216 \pm 40$ & - & - \\
\hline $0.1 \mathrm{~N}$ Acetic: $23+24$ & $0.705206 \pm 13$ & $0.706723 \pm 18$ & $0.706205 \pm 17$ & $0.708592 \pm 14$ & $0.708573 \pm 16$ \\
\hline $1.0 \mathrm{~N}$ Acetic & - & $0.706671 \pm 17$ & $0.706192 \pm 16$ & - & - \\
\hline $1.5 \mathrm{~N}$ Nitric & $0.705096 \pm 14$ & $0.706432 \pm 18$ & $0.706114 \pm 18$ & $0.708665 \pm 14$ & $0.708345 \pm 17$ \\
\hline $4.5 \mathrm{~N}$ Nitric & - & $0.706468 \pm 16$ & $0.706110 \pm 28$ & - & - \\
\hline $15.0 \mathrm{~N}$ Nitric & - & $0.706431 \pm 23$ & $0.705914 \pm 73$ & - & - \\
\hline
\end{tabular}

$(\mathrm{C})=$ continental deposit, $(\mathrm{M})=$ marine deposit, UMMP $=$ University of Michigan Museum of Paleontology, UCMP $=$ University of California, Berkeley, Museum of Paleontology. Errors are reported as $\pm 2 \sigma$. UMMP 58062, locality near Bend, OR; UCMP 136029 and 136030, Mehrten Fm., Stanislaus Co., CA; UCMP 119996, San Mateo Fm., San Diego Co., CA; UCMP 136028, Purisima Fm., Marin Co., CA. 


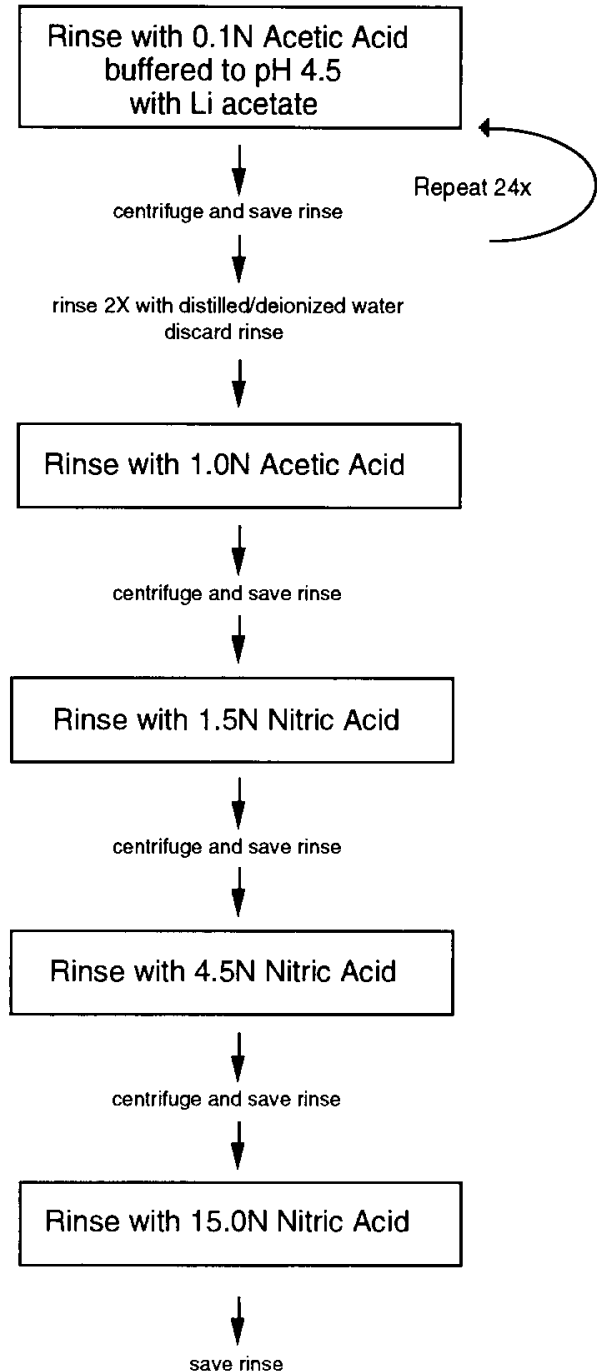

Fig. 2. Flow chart depicting protocol for stepwise selective leaching.

procedure was repeated 24 times, and each rinse was saved for analysis (Fig. 2). Following rinse 24, samples were rinsed twice with distilled water, which was discarded. Samples were then treated once with each of the following solutions: $1.0 \mathrm{~N}$ acetic acid $(12 \mathrm{~h}), 1.5 \mathrm{~N} \mathrm{HNO}_{3}(15 \mathrm{~min}), 4.5 \mathrm{~N}$ $\mathrm{HNO}_{3}(1-3 \mathrm{~h})$ and $15 \mathrm{~N} \mathrm{HNO}_{3}(1-3 \mathrm{~h})$ (using 0.04 $\mathrm{ml}$ of solution/mg of starting sample powder). Samples were completely digested in the final solution. To ensure sufficient volumes for chemical and isotopic analyses, consecutive sample rinses with $0.1 \mathrm{~N}$ acetic acid were combined after rinse 2 (e.g., $3+4,5+6$, through to $23+24$ ). For all fossils, $0.1 \mathrm{~N}$ acetic rinses 1 and $23+24$ were dedicated to $\mathrm{Sr}$ isotopic analysis, as were rinses $9+10$ and $17+18$ for the Turlock Lake specimens. Concentrated acid rinses were split, permitting both elemental and isotopic analysis. A bulk sample representing marine growth from the recent $S$. salar vertebra was treated with stepwise selective leaching as a control for elemental analysis.

Concentrations of $\mathrm{Sr}, \mathrm{Ca}$, and $\mathrm{P}$ were measured by atomic emission using a Leeman Labs


emission spectrometer. Solution matrix effects were minimal, and the precision was better than $2 \%$ for all elements, based on replicate analyses of gravimetric standards. The Sr blank in $1.0 \mathrm{ml}$ of the buffered $0.1 \mathrm{~N}$ acetic acid solution was 12 $\mathrm{ng}$, whereas blanks for $\mathrm{Ca}$ and $\mathrm{P}$ were below detection limits. Phosphorus concentration, and $\mathrm{Sr} / \mathrm{Ca}$ and $\mathrm{Ca} / \mathrm{P}$ values are presented in the Appendix.

Modern bone and bulk sediment samples were acid-digested for $\mathrm{Sr}$ isotopic analysis using standard techniques, then dried to a residue [29]. Hatchery water was acidified (using $1.0 \mathrm{ml} 15 \mathrm{~N}$ $\mathrm{HNO}_{3}$ /liter), and evaporated to a residue in a teflon beaker. Modern bone, sediment, water residues, and dried residues from rinses of fossil bones and teeth were dissolved in $2.5 \mathrm{~N} \mathrm{HCl}$, then $\mathrm{Sr}$ was isolated using standard ion exchange techniques [29]. Strontium was loaded onto single $\mathrm{Re}$ filaments with $\mathrm{Ta}_{2} \mathrm{O}_{5}$. Isotopic compositions were determined on a V.G. Sector mass spectrometer with seven Faraday detectors employing multidynamic peak switching. Total process blanks averaged $0.1 \mathrm{ng}$. All blanks were negligible relative to the $\mathrm{Sr}$ contributed by the samples. The standard NBS 987 averaged $0.710255 \pm 15(2 \sigma)$ during these analyses.

\section{Sr isotopic composition of modern salmon and hatchery waters}

Changes in ${ }^{87} \mathrm{Sr} /{ }^{86} \mathrm{Sr}$ value across the vertebral centra of modern salmon were consistent with freshwater to marine migration. In the Salmo salar from Maine, the first two samples, moving out from the center of the vertebra, had ${ }^{87} \mathrm{Sr} /{ }^{86} \mathrm{Sr}$ values $(0.7114$ and 0.7099$)$ that were significantly greater than modern seawater (0.70918) (Fig. 3, 


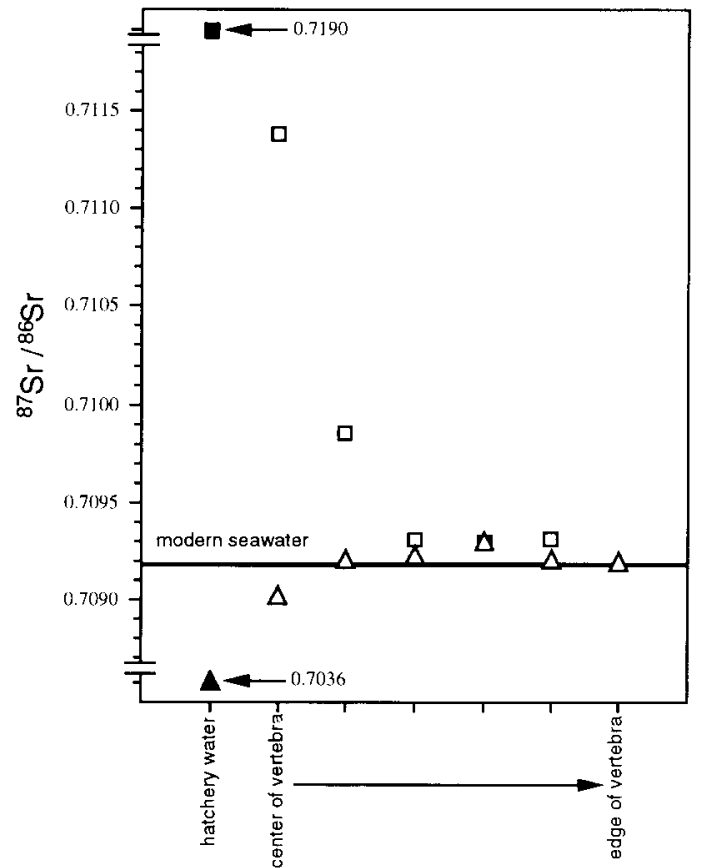

Fig. 3. Variation in ${ }^{87} \mathrm{Sr} /{ }^{86} \mathrm{Sr}$ value across vertebral centra of modern Salmo salar, and Oncorhynchus kisutch (UMMZ 186653). Samples from the center of vertebrae record early, freshwater growth, whereas samples towards the edge of vertebrae record later, marine life. Note breaks in scale required for plotting hatchery waters. Values for hatchery water are supplied by numbers next to filled symbols. The modern seawater ${ }^{87} \mathrm{Sr} /{ }^{86} \mathrm{Sr}$ value of 0.70918 is marked by a line (from [11]), but reduced by 0.00007 to account for interlaboratory differences for the NBS 987 standard between Univ. of Michigan and U.C.L.A.

Table 1). These high values result from juvenile growth in hatchery waters with a value of 0.71903 , and ultimately reflect $\mathrm{Sr}$ derived from old granitic rocks. The first sample from a hatchery-reared Oncorhynchus kisutch (UMMZ 186653) had a lower ${ }^{87} \mathrm{Sr} /{ }^{86} \mathrm{Sr}$ value $(0.7090)$ than modern seawater. Here, hatchery water had a low ${ }^{87} \mathrm{Sr} /{ }^{86} \mathrm{Sr}$ value $(0.7036)$ due to the influence of young basaltic rocks. Natal water samples were not available for the museum specimens. However, the $O$. kisutch from the mouth of the Columbia River (UMMZ 186654) and the specimen from the Bonneville Hatchery had identical $\mathrm{Sr}$ isotope trends (Table 1). In the O. nerka from the Quinault River (UMMZ 94902), the first sample was hardly distinguishable from modern seawater, and was shifted toward a higher value, not a lower value, like the other salmon from the Pacific
Northwest (Table 1). However, the Quinault River drains a restricted region of the Coast Range that may have a unique $\mathrm{Sr}$ isotopic composition.

All specimens had $\mathrm{Sr}$ isotopic compositions that progressed from freshwater-influenced to fully marine across a single vertebra. Yet the freshwater growth portions of hatchery-reared specimens had different ${ }^{87} \mathrm{Sr} /{ }^{86} \mathrm{Sr}$ value than hatchery water. Perhaps Sr was remobilized by small-scale bone remodeling after initial bone formation. Remobilization of $\mathrm{Sr}$ from freshwater growth layers had no great influence on the composition of bone deposited later, under marine conditions. Samples from the periphery of vertebral centra had ${ }^{87} \mathrm{Sr} /{ }^{86} \mathrm{Sr}$ values nearly identical to seawater. Consequently, the outer edges of fossil salmon vertebrae should also yield marine $\mathrm{Sr}$ isotopic compositions, unless they are diagenetically altered.

\section{Chemical and $\mathrm{Sr}$ isotopic compositions of fos- sil salmon}

The presence of minerals other than biogenic hydroxyapatite can be detected through analysis of $\mathrm{Ca} / \mathrm{P}$ values of sample rinses. Stoichiometric carbonate hydroxyapatite (4 wt. $\% \mathrm{CO}_{3}, 9: 1$ $\mathrm{OH}: \mathrm{F}$ ) has a $\mathrm{Ca}$ to $\mathrm{P}$ mass ratio of 2.4 , whereas biogenic hydroxyapatite averages 2.0 [1]. The $\mathrm{Ca} / \mathrm{P}$ value of rinses from the modern sample ranged from 2.0 to 3.6 (Fig. 4, Appendix). Most rinses for fossil salmon fell within this range of plausible biogenic values. By $0.1 \mathrm{~N}$ acetic rinse $17+18$, the $\mathrm{Ca} / \mathrm{P}$ value of all the fossils were less than the value of the modern control. Porefilling carbonates generate elevated $\mathrm{Ca} / \mathrm{P}$ values, thus this crossover indicates complete removal of any calcite initially present in the samples. Most of the hydroxyapatite in each sample dissolved in the $1.5 \mathrm{~N}$ nitric rinse (see $[\mathrm{P}]$ in Appendix). This rinse had the smallest range of $\mathrm{Ca} / \mathrm{P}$ values, with similar values for fossils (mean $=2.4$ ) and the modern control (2.2). This cluster of data falling near the stoichiometric $\mathrm{Ca} / \mathrm{P}$ value of 2.4 is evidence that the $1.5 \mathrm{~N}$ nitric rinse dissolved recrystallized apatite. Uncontaminated biogenic hydroxyapatite, if present at all, must have been leached in rinses collected after the complete removal of calcite (i.e., after $0.1 \mathrm{~N}$ acetic rinse $17+18$ ), but before the dissolution of recrystal- 


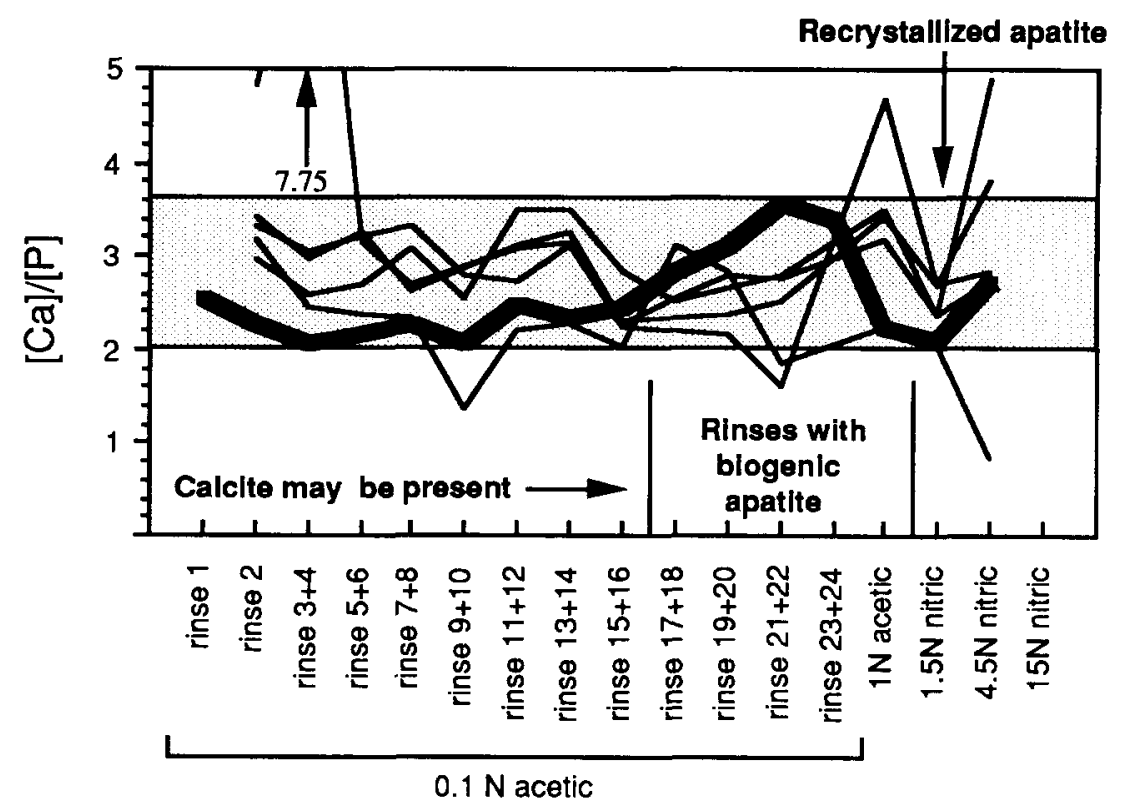

Fig. 4. Mass ratio of $\mathrm{Ca}$ to $\mathrm{P}$ in stepwise selective rinses from marine growth portion of modern and fossil salmon. Values for the modern salmon are indicated by the thick bold line, and the range of values seen in this modern control is marked with stippling (2.0-3.6). Rinses from different fossil salmon are plotted as thin lines.

lized apatite (i.e., before $1.5 \mathrm{~N}$ nitric rinse) (Fig. 4).

If biogenic hydroxyapatite was isolated in the later dilute acetic acid rinses, these rinses should yield biologically plausible $\mathrm{Sr} / \mathrm{Ca}$ values [23]. Pore-filling carbonate minerals should have higher $\mathrm{Sr} / \mathrm{Ca}$ values than biogenic hydroxyapatite [23], whereas recrystallized apatite should have lower values [23]. Values ranging from 0.1 to $6.0 \times 10^{-3}$ and from 0.7 to $6.0 \times 10^{-3}$ have been reported for modern continental and marine animals, respectively [30,31]. However, analyses of fish bone are rare and frequently yield high $\mathrm{Sr} / \mathrm{Ca}$ values. Values for our modern marine control ranged from 1.7 to $5.1 \times 10^{-3}$ in different rinses (Appendix). With one exception, all fossils had $\mathrm{Sr} / \mathrm{Ca}$ values that decreased from slightly higher values in early rinses to plausible, marine values $\left(\sim 2.4\right.$ to $\left.6.4 \times 10^{-3}\right)$ in the late dilute acetic rinses (Appendix). The pattern of $\mathrm{Sr} / \mathrm{Ca}$ values decreasing to plausible plateaus in late acetic acid rinses supports the hypothesis that all diagenetic calcite is removed in early rinses. Although $\mathrm{Sr} / \mathrm{Ca}$ values also decreased in the Loretta salmon (UCMP 119996), extremely high values that could not be attributed to biogenic hydroxyapatite were recovered from all the rinses $(\sim 11$ to
$33 \times 10^{-3}$ ). Either the apatite crystals in this specimen were massively contaminated by sedimentary $\mathrm{Sr}$ or Sr-bearing minerals other than apatite and calcite were present.

Most specimens met the criteria set out for recognizing biogenic hydroxyapatite from elemental composition: (1) late dilute acetic acid rinses had apatitic $\mathrm{Ca} / \mathrm{P}$ values, and (2) $\mathrm{Sr} / \mathrm{Ca}$ values in these rinses were biologically plausible. If this interpretation was correct, then these rinses should have had ${ }^{87} \mathrm{Sr} /{ }^{86} \mathrm{Sr}$ values characteristic of late Miocene seawater $(\sim 0.7088$ to 0.7090 , $[11,12])$. If, however, these specimens were contaminated by diagenetic $\mathrm{Sr}$, then their ${ }^{87} \mathrm{Sr} /{ }^{86} \mathrm{Sr}$ values should deviate from late Miocene seawater and trend toward the composition of sedimentary $\mathrm{Sr}$ at the burial site.

All fossil salmon buried in continental settings (Turlock Lake, Gateway) had ${ }^{87} \mathrm{Sr} /{ }^{86} \mathrm{Sr}$ values in late dilute acetic acid rinses very different from the value for late Miocene seawater (Table 2, Fig. 5 ). When values from tooth enamel and bone from the same locality (Turlock Lake) were compared, those for enamel were closer to the marine ratio than values for bone. Isotopic values for specimens buried in nearshore, clasticdominated marine deposits (Loretta, Drakes Bay), 


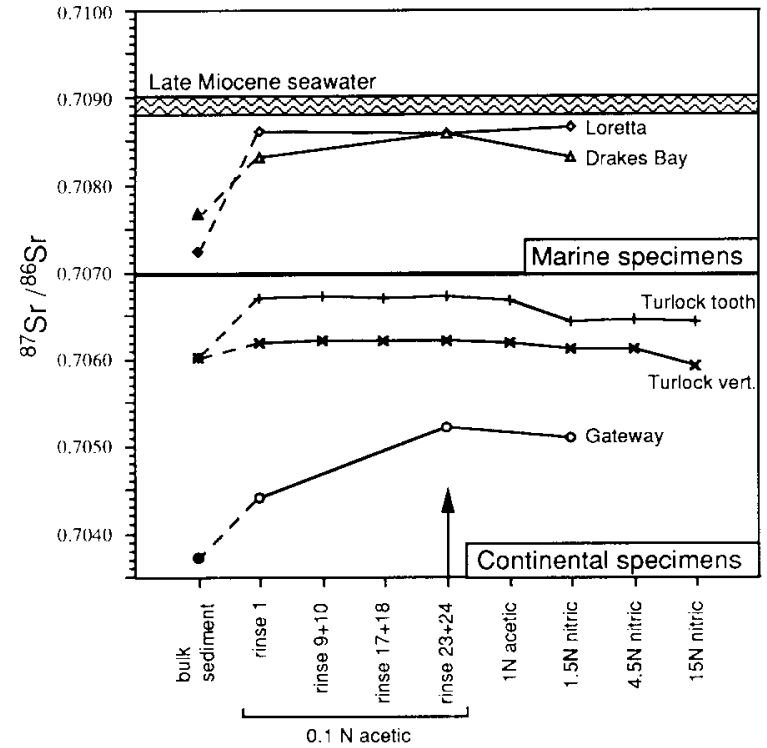

Fig. 5. Change in ${ }^{87} \mathrm{Sr} /{ }^{86} \mathrm{Sr}$ value in stepwise selective rinses from fossil salmon vertebrae and enamel, and bulk sediment composition from continental and marine environments. The range of observed late Miocene seawater ${ }^{87} \mathrm{Sr} /{ }^{86} \mathrm{Sr}$ values is indicated. Arrow points to sample rinses which typically have the most original $\mathrm{Sr}$.

although closer to late Miocene marine values, did not overlap the marine range (Table 2, Fig. 5). All specimens except the Loretta salmon had late dilute acetic acid rinses closer to the marine ${ }^{87} \mathrm{Sr} /{ }^{86} \mathrm{Sr}$ value than either the early rinses or the late concentrated acid rinses. This isotopic pattern indicates that late dilute rinses did indeed contain more original $\mathrm{Sr}$ than either early rinses, which were contaminated by Sr-bearing carbonates, or concentrated acid rinses, which dissolved recrystallized apatite that had incorporated sedimentary Sr. However, even these late dilute acetic acid rinses were massively contaminated with diagenetic Sr.

\section{Discussion}

Despite the fact that element ratios suggest that primary marine $\mathrm{Sr}$ might have been isolated by stepwise selective leaching of fossil salmon, the isotopic evidence clearly demonstrates that the specimens were massively contaminated by diagenetic $\mathrm{Sr}$ of continental origin. Tooth enamel, though slightly more retentive of original $\mathrm{Sr}$ than bone, was also heavily contaminated. As ex- pected, late dilute acetic acid rinses contained the greatest amount of primary $\mathrm{Sr}$, yet even these rinses did not yield marine ${ }^{87} \mathrm{Sr} /{ }^{86} \mathrm{Sr}$ values. For the Gateway salmon, assuming a diagenetic endmember value of 0.70372 (derived from bulk sediment), and a biogenic endmember of 0.70885 , only $29 \%$ of the $\mathrm{Sr}$ in late dilute acetic acid rinses was marine. For the Turlock Lake tooth and vertebra, the values were $25 \%$ and $7 \%$, respectively. However, diagenetic fluids need not have had exactly the same isotopic composition as bulk sediment. Here, a two-component approach might be oversimplified. If diagenetic fluids had ${ }^{87} \mathrm{Sr} /$ ${ }^{86} \mathrm{Sr}$ values higher than bulk sediment, the actual amount of original $\mathrm{Sr}$ in the fossils could be even lower than our estimates.

Our results have substantial ramifications for studies of $\mathrm{Sr}$ concentration and ${ }^{87} \mathrm{Sr} /{ }^{86} \mathrm{Sr}$ values in fossils. Differences in $\mathrm{Sr}$ concentration have been used to monitor meat consumption in archaeological and paleontological studies [2-4]. Because much of the $\mathrm{Sr}$ in bones and teeth may be introduced after death, there is no reason to believe that original $\mathrm{Sr}$ concentrations are retained in the sample rinses. Without a reliable method for isolating biogenic hydroxyapatite, studies employing $\mathrm{Sr}$ concentration are problematic, particularly for more ancient specimens.

Strontium isotopes have been used to explore the diet, habitats and, potentially, the migration patterns of ancient organisms [5-8]. For example, the ${ }^{87} \mathrm{Sr} /{ }^{86} \mathrm{Sr}$ values of fossil fishes may indicate if they were freshwater or marine residents. It may sometimes be possible to distinguish between such profoundly different habitats, even in diagenetically altered material. However, more subtle habitat determinations (e.g., between marine and brackish water [8]) are precluded. Similarly, studies of migration are highly problematic, because they require the presence of a clearly biogenic, not a diagenetic, signal. The observed variations in $\mathrm{Sr}$ isotopic composition between different rinses from the same individual suggested that a small fraction of original $\mathrm{Sr}$ can be retained. If applied in a comparative study of a fossil fauna, $\mathrm{Sr}$ isotopic analysis might indicate which fossils were native and which were immigrants. However, to use migratory animals for marine-continental correlation, the original marine ${ }^{87} \mathrm{Sr} /{ }^{86} \mathrm{Sr}$ value must be preserved with high 
fidelity in continentally deposited specimens. Our results suggest that this is highly unlikely.

Our marine-deposited specimens did not yield ${ }^{87} \mathrm{Sr} /{ }^{86} \mathrm{Sr}$ values appropriate for late Miocene oceans. Previous investigations of $\mathrm{Sr}$ concentration and isotopic composition in fish bones and teeth concluded that either fossils preserve lifetime values, or they incorporate $\mathrm{Sr}$ during early diagenetic alteration near the sediment/water interface [9-11]. Either way, fossils would reflect the isotopic and elemental composition of the overlying ocean. Our results from marine-deposited salmon demonstrated that $\mathrm{Sr}$ was incorporated after burial from surrounding siliciclastic minerals that were isotopically distinct from the Miocene ocean. Similarly, recent analyses of REEs in fish teeth have demonstrated enrichment following burial by later diagenetic pore fluids [32]. The relative success of previous studies using marine fish bones and teeth [9-11] indicates that early diagenetic fluids probably had ${ }^{87} \mathrm{Sr} /{ }^{86} \mathrm{Sr}$ values similar to lifetime values. However, even in these earlier studies of marine fish, diagenetic effects were detected.

Whereas $\mathrm{Sr}$ isotopic analysis of geologically ancient bones and teeth is problematic, the technique may hold promise for more recent materials [6]. Selective leaching did isolate a fraction with proportionally more original Sr. In specimens that are not so thoroughly altered, the technique may isolate purely biogenic hydroxyapatite. The differences in ${ }^{87} \mathrm{Sr} /{ }^{86} \mathrm{Sr}$ value between the Turlock Lake tooth and vertebra indicated that enamel did retain a greater proportion of original $\mathrm{Sr}$ than bone. Although Oncorhynchus enamel did not yield completely original $\mathrm{Sr}$, its enamel coating was very thin $(<1 \mathrm{~mm})$ and thus was more susceptible to diagenetic alteration. Better results may be obtained through analysis of vertebrate teeth with thicker enamel. Finally, it may be possible to screen samples for signs of massive recrystallization before isotopic analysis using infrared spectroscopy [22].

Strontium isotopes and chemical composition may offer monitors of migration in modern vertebrates. By examining the $\mathrm{Sr}$ isotopic composition of material accreted during different times of life, shifts corresponding to freshwater to marine migration were apparent. Our inability to precisely reconstruct freshwater ${ }^{87} \mathrm{Sr} /{ }^{86} \mathrm{Sr}$ values may have resulted from either sampling at too coarse a spatial scale, or from remobilization of $\mathrm{Sr}$ during the animal's life. In any case, migrational analysis was still possible because the attenuation of the freshwater $\mathrm{Sr}$ isotopic signal was not complete. Migration could also be studied by examining the apatite grown late in life in individuals in a freshwater population to determine the percentage that were marine immigrants.

\section{Conclusions}

(1) Strontium isotopic analysis of accreted hardparts in modern salmon can be used to monitor freshwater to marine migrations, although it may not be possible to reconstruct the precise value of natal waters from the earliest accreted bone.

(2) Although most fossil salmon treated with stepwise selective leaching had apatitic $\mathrm{Ca} / \mathrm{P}$ and plausible $\mathrm{Sr} / \mathrm{Ca}$ in late dilute acetic acid rinses, isotopic analysis demonstrated that the $\mathrm{Sr}$ in these rinses, and in all rinses, was mostly diagenetic/ sedimentary in origin. Alteration was so pervasive that we could not retrieve late Miocene marine isotopic values from salmon buried in marine sites with clastic sediments. Therefore, these specimens cannot be used to correlate marine and continental strata.

(3) Despite alteration, we were able to confirm that salmon buried in freshwater continental deposits, were marine immigrants.

(4) Until reliable techniques for separating primary and diagenetic Sr are developed, analyses of the $\mathrm{Sr}$ isotopic and elemental composition of bone and teeth must be approached and interpreted with caution.

\section{Acknowledgements}

We appreciate advice, comments, and technical assistance provided by A.K. Behrensmeyer, S.J. Carpenter, D.L. Dettman, D.C. Fisher, R. Keller, K.C. Lohmann, D. Long, S. Nakai, J.R. O'Neil, B. Opdyke, and A. Sillen. M.L. Fogel, B. Luz, J.C. Sealy, N. Tuross, and three anonymous reviewers provided thoughtful reviews. We thank J.H. Hutchison and D. Long at the Museum of Paleontology, U.C. Berkeley, D. Nelson at the University of Michichan Museum of Zoology, E.T. 
Baum at the Atlantic Sea Run Salmon Commission, D.C. Kimball with U.S. Department of Interior Fish and Wildlife Service, T.F. King at Craig Brook National Fish Hatchery, and K. Bourne at the Bonneville Fish Hatchery for access to specimens and hatchery water. Thanks are also extended to Bonnie Miljour for assistance with drafting. Financial assistance was supplied by the Scott Turner Fund of the Department of Geolog- ical Sciences at the University of Michichan, by NSF grants EAR-8616061, EAR-8804072, and EAR-9004413 (to A.N.H.), and EAR-8720510 and EAR-9096176 (to L.M.W.), by the Research Partnerships Program of the Rackham School of Graduate Studies, University of Michigan, by the National Museum of Natural History, Smithsonian Institution, and by the Geophysical Laboratory of the Carnegie Institution of Washington.

APPENDIX

$\mathrm{P}$ concentration, $\mathrm{Sr} / \mathrm{Ca}$, and $\mathrm{Ca} / \mathrm{P}$ values for rinses collected during stepwise selective leaching of modern and fossil salmon

\begin{tabular}{|c|c|c|c|c|c|c|c|c|c|}
\hline \multirow[t]{3}{*}{ Sample rinse } & \multicolumn{3}{|c|}{ Salmo salar } & \multirow{2}{*}{\multicolumn{3}{|c|}{$\begin{array}{l}\text { Turlock Lake tooth } \\
\text { (UCMP 136029) }\end{array}$}} & \multirow{2}{*}{\multicolumn{3}{|c|}{$\begin{array}{l}\text { Turlock Lake vertebra } \\
\text { (UCMP 136030) }\end{array}$}} \\
\hline & \multirow{2}{*}{$\overline{\mathrm{Ca} / \mathrm{P}}$} & \multirow{2}{*}{$\mathrm{Sr} / \mathrm{Ca}$} & \multirow{2}{*}[\mathrm{P}]{} & & & & & & \\
\hline & & & & $\mathrm{Ca} / \mathrm{P}$ & $\mathrm{Sr} / \mathrm{Ca}$ & {$[\mathrm{P}]$} & $\mathrm{Ca} / \mathrm{P}$ & $\mathrm{Sr} / \mathrm{Ca}$ & {$[\mathrm{P}]$} \\
\hline $0.1 \mathrm{~N}$ Acetic: 1 & 2.6 & 5.14 & 7.5 & - & - & - & - & - & - \\
\hline $0.1 \mathrm{~N}$ Acetic: 2 & 2.3 & 4.52 & 8.4 & 4.8 & 5.45 & 1.1 & 3.4 & 5.27 & 4.6 \\
\hline $0.1 \mathrm{~N}$ Acetic: $3+4$ & 2.0 & 4.29 & 20.8 & 7.8 & 5.60 & 0.4 & 3.0 & 5.41 & 4.4 \\
\hline $0.1 \mathrm{~N}$ Acetic: $5+6$ & 2.2 & 3.86 & 13.4 & 3.1 & 6.03 & 2.2 & 3.2 & 5.49 & 3.4 \\
\hline $0.1 \mathrm{~N}$ Acetic: $7+8$ & 2.3 & 3.73 & 11.5 & 2.7 & 6.29 & 2.3 & 2.6 & 4.81 & 2.9 \\
\hline $0.1 \mathrm{~N}$ Acetic: $9+10$ & 2.1 & 3.50 & 16.3 & - & - & - & - & - & - \\
\hline $0.1 \mathrm{~N}$ Acetic: $11+12$ & 2.5 & 3.25 & 8.4 & 3.1 & 6.08 & 1.4 & 3.1 & 4.50 & 2.0 \\
\hline $0.1 \mathrm{~N}$ Acetic: $13+14$ & 2.3 & 3.08 & 7.8 & 3.1 & 5.93 & 1.2 & 3.3 & 4.85 & 1.9 \\
\hline $0.1 \mathrm{~N}$ Acetic: $15+16$ & 2.4 & 2.65 & 7.0 & 2.2 & 5.43 & 1.1 & 2.3 & 4.72 & 2.6 \\
\hline $0.1 \mathrm{~N}$ Acetic: $17+18$ & 2.8 & 2.65 & 5.0 & - & - & - & - & - & - \\
\hline $0.1 \mathrm{~N}$ Acetic: $19+20$ & 3.1 & 2.39 & 3.8 & 2.2 & 5.25 & 1.4 & 2.4 & 4.10 & 2.0 \\
\hline $0.1 \mathrm{~N}$ Acetic: $21+22$ & 3.6 & 2.42 & 2.9 & 1.6 & 5.38 & 1.7 & 2.5 & 4.10 & 2.0 \\
\hline $0.1 \mathrm{~N}$ Acetic: $23+24$ & 3.4 & 2.13 & 2.9 & - & - & - & - & - & - \\
\hline $1.0 \mathrm{~N}$ Acetic & 2.2 & 2.17 & 30.5 & 4.7 & 4.60 & 2.6 & 3.4 & 3.82 & 5.8 \\
\hline $1.5 \mathrm{~N}$ Nitric & 2.1 & 1.92 & 54.4 & 2.7 & 4.00 & 47.5 & 2.7 & 3.54 & 42.7 \\
\hline $4.5 \mathrm{~N}$ Nitric & 2.7 & 1.71 & 0.6 & 3.8 & 3.91 & 0.9 & 2.8 & 3.82 & 0.5 \\
\hline 15.0N Nitric & - & - & - & n.d. & n.d. & 0.0 & n.d. & n.d. & 0.0 \\
\hline
\end{tabular}

\begin{tabular}{|c|c|c|c|c|c|c|c|c|c|}
\hline \multirow[t]{2}{*}{ Sample rinse } & \multicolumn{3}{|c|}{$\begin{array}{l}\text { Gateway } \\
\text { (UMMP 58062) }\end{array}$} & \multicolumn{3}{|c|}{$\begin{array}{l}\text { Loretta Street } \\
\text { (UCMP 119996) }\end{array}$} & \multicolumn{3}{|c|}{$\begin{array}{l}\text { Drakes Bay } \\
\text { (UCMP 136028) }\end{array}$} \\
\hline & $\mathrm{Ca} / \mathrm{P}$ & $\mathrm{Sr} / \mathrm{Ca}$ & {$[\mathrm{P}]$} & $\mathrm{Ca} / \mathrm{P}$ & $\mathrm{Sr} / \mathrm{Ca}$ & {$[\mathrm{P}]$} & $\mathrm{Ca} / \mathrm{P}$ & $\mathrm{Sr} / \mathrm{Ca}$ & {$[\mathbf{P}]$} \\
\hline $0.1 \mathrm{~N}$ Acetic: 1 & - & - & - & - & - & - & - & - & - \\
\hline $0.1 \mathrm{~N}$ Acetic: 2 & 3.3 & 3.10 & 2.3 & 3.2 & 26.5 & 1.2 & 3.0 & 7.17 & 2.4 \\
\hline $0.1 \mathrm{~N}$ Acetic: $3+4$ & 3.0 & 2.90 & 4.2 & 2.4 & 31.9 & 1.2 & 2.6 & 6.64 & 5.2 \\
\hline $0.1 \mathrm{~N}$ Acetic: $5+6$ & 3.2 & 2.71 & 4.3 & 2.4 & 32.6 & 0.9 & 2.7 & 6.25 & 3.4 \\
\hline $0.1 \mathrm{~N}$ Acetic: $7+8$ & 3.3 & 2.55 & 3.9 & 2.3 & 31.3 & 0.8 & 3.1 & 6.38 & 2.9 \\
\hline $0.1 \mathrm{~N}$ Acetic: $9+10$ & 2.8 & 2.48 & 3.6 & 1.4 & 28.4 & 1.0 & 2.6 & 6.30 & 2.5 \\
\hline $0.1 \mathrm{~N}$ Acetic: $11+12$ & 2.7 & 2.55 & 3.5 & 2.2 & 25.6 & 0.6 & 3.5 & 6.38 & 2.5 \\
\hline $0.1 \mathrm{~N}$ Acetic: $13+14$ & 3.1 & 2.50 & 3.6 & 2.3 & 23.0 & 0.6 & 3.5 & 6.51 & 2.8 \\
\hline $0.1 \mathrm{~N}$ Acetic: $15+16$ & 2.3 & 2.58 & 3.0 & 2.0 & 21.5 & 0.7 & 2.8 & 6.28 & 2.7 \\
\hline $0.1 \mathrm{~N}$ Acetic: $17+18$ & 2.6 & 2.65 & 3.3 & 3.1 & 16.3 & 0.4 & 2.5 & 6.23 & 2.6 \\
\hline $0.1 \mathrm{~N}$ Acetic: $19+20$ & 2.8 & 2.54 & 2.6 & 2.8 & 18.8 & 0.5 & 2.6 & 6.44 & 2.2 \\
\hline $0.1 \mathrm{~N}$ Acetic: $21+22$ & 2.8 & 2.38 & 3.3 & 1.9 & 16.0 & 0.6 & 2.8 & 6.24 & 2.0 \\
\hline $0.1 \mathrm{~N}$ Acetic: $23+24$ & - & - & - & - & - & - & - & - & - \\
\hline $1.0 \mathrm{~N}$ Acetic & 3.2 & 2.30 & 10.6 & 2.2 & 11.1 & 7.6 & 3.5 & 6.48 & 10.0 \\
\hline $1.5 \mathrm{~N}$ Nitric & 2.4 & 2.00 & 98.4 & 2.0 & 16.4 & 123 & 2.4 & 6.68 & 84.5 \\
\hline $4.5 \mathrm{~N}$ Nitric & 4.9 & 1.91 & 2.1 & 0.8 & 366 & 4.5 & 2.7 & 6.82 & 1.2 \\
\hline $15.0 \mathrm{~N}$ Nitric & 0.5 & 0.83 & 0.3 & n.d. & 61.8 & 0.0 & n.d. & 7.37 & 0.0 \\
\hline
\end{tabular}

$[\mathrm{P}]=\mu \mathrm{g}$ element in rinse $/ \mathrm{mg}$ of starting sample powder; $\mathrm{Ca} / \mathrm{P}=\mathrm{mg} \mathrm{Ca} / \mathrm{mg} \mathrm{P}$ in rinse; $\mathrm{Sr} / \mathrm{Ca}=\mathrm{mg} \mathrm{Sr} / \mathrm{mg} \mathrm{Ca}$ in rinse, $\mathrm{multiplied}$ by $10^{3} ;-=$ rinses that were not measured; n.d. = values that are non-determinable. Actual $\mathrm{Sr} / \mathrm{Ca}$ values are presented in text. 


\section{References}

1 R.Z. LeGeros, Apatites in biological systems, in: Inorganic Biological Crystal Growth, vol. 2, B.R. Pamplin, ed., Prog. Crystal Growth Charact. 4, 1-45, 1981.

2 H. Toots and M.R. Voorhies, Strontium in fossil bones and the reconstruction of food chains, Science 149, 854855,1965 .

3 M.J. Schoeninger, Diet and status at Chalcatzingo: some empirical and technical aspects of strontium analysis, Am. J. Phys. Anthropol. 51, 295-310, 1979.

4 A. Sillen and M. Kavanagh, Strontium and paleodietary research: a review, Yearb. Phys. Anthropol. 25, 67-90, 1982.

5 J.E. Ericson, Strontium isotope characterization in the study of prehistoric human ecology, J. Hum. Evol. 14, 503-514, 1985.

6 J.C. Sealy, N.J. van der Merwe, A. Sillen, F.J. Kruger and H.W. Krueger, ${ }^{87} \mathrm{Sr} /{ }^{86} \mathrm{Sr}$ as a dietary indicator in modern and archaeological bone, J. Archaeol. Sci. 18, 399-416, 1991.

7 E.J. Dasch and K.S.W. Campbell, Strontium-isotope evidence for marine or freshwater origin of fossil Dipnoans and Arthrodires, Nature 227, 1159, 1970.

8 B. Schmitz, G. Aåberg, L. Werdelin, P. Forey and S.E. Bendix-Almgreen, ${ }^{87} \mathrm{Sr} /{ }^{86} \mathrm{Sr}, \mathrm{Na}, \mathrm{F}, \mathrm{Sr}$, and $\mathrm{La}$ in skeletal fish debris as a measure of the paleosalinity of fossil-fish habitats, Geol. Soc. Am. Bull. 103, 786-794, 1991.

9 H. Staudigel, P. Doyle and A. Zindler, $\mathrm{Sr}$ and $\mathrm{Nd}$ isotope systematics in fish teeth, Earth Planet. Sci. Lett. 76, 45-56, 1985.

10 P. Grandjean, H. Cappetta, A. Michard and F. Albarede, The assessment of REE patterns and ${ }^{143} \mathrm{Nd} /{ }^{144} \mathrm{Nd}$ ratios in fish remains, Earth Planet. Sci. Lett. 84, 181-196, 1987.

11 H.F. Shaw and G.J. Wasserburg, Sm-Nd in marine carbonates and phosphates, Geochim. Cosmochim. Acta 49, 503518, 1985 .

12 D.J. DePaolo, Detailed record of the Neogene Sr isotopic evolution of seawater from DSDP Site 590B, Geology 14, $103-106,1986$.

13 J.A. McKenzie, D.A. Hodell, P.A. Mueller and D.W. Mueller, Application of $\mathrm{Sr}$ isotopes to late Miocene-early Pliocene stratigraphy, Geology 16, 1022-1025, 1988.

14 A. Sillen, Diagenesis of the inorganic phase of cortical bone, in: Chemistry of Prehistoric Human Bone, T.D. Price, ed., pp. 211-229, Cambridge University Press, Cambridge, 1989.

15 J.B. Lambert, S.M. Vlasak, S.G. Weiner and J.E. Buikstra, Induced metal-ion exchange in excavated human bone, J. Archaeol. Sci. 12, 85-92, 1985.

16 N. Tuross, A.K. Behrensmeyer and E.D. Eanes, Strontium increases and crystallinity changes in taphonomic and archaeological bone, J. Archaeol. Sci. 16, 661-672, 1989.

17 R.B. Parker and H. Toots, Minor elements in fossil bone, Geol. Soc. Am. Bull. 81, 925-932, 1970.

18 J.B. Lambert, S.M. Vlasak, A.C. Thometz and J.E. Buik- stra, A comparative study of the chemical analysis of ribs and femurs in Woodland populations, Am. J. Phys. Anthropol. 59, 289-294, 1982.

19 B.K. Nelson, M.J. DeNiro, M.J. Schoeninger, D.J. DePaolo and P.E. Hare, Effects of diagenesis on strontium, carbon, nitrogen, and oxygen concentration and isotopic composition of bone, Geochim. Cosmochim. Acta 50, 194$199,1986$.

20 E.D. Eanes and A.S. Posner, A note on the crystal growth of hydroxyapatite precipitated from aqueous solutions, Mater. Res. Bull. 5, 12-21, 1970.

21 M.J. Schoeninger, Diet and evolution of modern human form in the Middle East, Am. J. Phys. Anthropol. 25, 67-90, 1982.

22 A. Shemesh, Crystallinity and diagenesis of sedimentary apatites, Geochim. Cosmochim. Acta 54, 2433-2438, 1990.

23 A. Sillen, Biogenic and diagenetic $\mathrm{Sr} / \mathrm{Ca}$ in Plio-Pleistocene fossils of the Omo Shungura Formation, Paleobiology 12, 311-323, 1986.

24 W.A. Berggren, D.V. Kent, J.J. Flynn and J.A. van Couvering, Cenozoic geochronology, Geol. Soc. Am. Bull. 96, $1407-1418,1985$.

25 R.G. Randall, M.C. Healey and J.B. Dempson, Variability in length of freshwater residence of salmon, trout, and char, in: Common Strategies of Anadromous and Catadromous Fishes, M.J. Dadswell, R.J. Klauda, C.M. Moffitt, R.L. Saunders, R.A. Rulifson and J.E. Cooper, eds., pp. 27-41, American Fisheries Society, Bethesda, Md., 1987.

26 R.F. Stearley and J.D. Stewart, Phylogenetic relationships of Oncorhynchus rastrosus, J. Vert. Paleontol. 10, Suppl., p. 43A, 1990.

27 R.F. Stearley, Historical ecology of Salmoninae, with special reference to Oncorhynchus, in: Systematics, Historical Ecology, and the North American Freshwater Fishes, R.L. Mayden, ed., in press, Stanford University Press, Stanford, Calif.

28 G.R. Smith, A dwarf species of Oncorhynchus ("Smilodonichthys") from the Miocene Chalk Hills Formation, southwest Idaho, J. Vert. Paleontol. 10, Suppl., p. $42 \mathrm{~A}, 1990$.

29 A.N. Halliday, G.A. Mahood, P. Holden, J.M. Metz, T.J. Dempster and J.P. Davidson, Evidence for long-residence time of rhyolitic magma in the Long Valley magmatic system: the isotopic record in precaldera lavas of Glass Mountain, Earth Planet. Sci. Lett. 94, 274-290, 1989.

30 J.C. Sealy and A. Sillen, $\mathrm{Sr}$ and $\mathrm{Sr} / \mathrm{Ca}$ in marine and terrestrial foodwebs in southwestern Cape, South Africa, J. Archaeol. Sci. 15, 425-438, 1988.

31 A. Sillen, Elemental and isotopic analyses of mammalian fauna from southern Africa and their implications for paleodietary research, Am. J. Phys. Anthropol. 76, 49-60, 1988.

32 K. Toyoda and M. Tokonami, Diffusion of rare-earth elements in fish teeth from deep-sea sediments, Nature $345,607-609,1990$. 